\title{
The 75th Anniversary of the Victory of Russian Memory Politics
}

\section{Preliminary Conclusions}

\section{Vasilisa S. Beshkinskaya, Alexei I. Miller}

\author{
Vasilisa S. Beshkinskaya \\ European University at Saint-Petersburg, Russia \\ Department of History \\ Student
}

ResearcherID: AAW-1855-2020

ORCID: 0000-0002-3292-9880

E-mail:vasilisa_lukina@inbox.ru

Tel.: +7 (812) 386-7634

Address: European University at St. Petersburg,

6/1A Gagarinskaya Str., St. Petersburg 191187, Russia.

\author{
Alexei I. Miller \\ European University at Saint-Petersburg, Russia \\ Department of History \\ Professor; \\ Center for the Study of Cultural Memory and Symbolic Politics \\ Research Director
}

ORCID: 0000-0001-8139-0976

ResearcherID: Z-1451-2019

Scopus AuthorID: 56321369000

E-mail: amiller@eu.spb.ru

Tel.: +7 (812) 386-7634

Address: European University at St. Petersburg,

6/1A Gagarinskaya Str., St. Petersburg 191187, Russia.

This paper was prepared as part of the project "A Comprehensive Comparative Study of Memory Politics in Russia and the International Arena: Actors, Strategies, Tools" with financial support from the Russian Science Foundation, grant No. 17-18-01589.

DOI: $10.31278 / 1810-6374-2020-18-3-200-232$ 


\begin{abstract}
The article studies events organized by the Russian authorities as part of the celebrations marking the 75th anniversary of the Victory in the Great Patriotic War of 1941-1945. The focus is on changes in the celebration plans due to the coronavirus epidemic, which made mass events impossible. The article analyzes the change of the target audience, the shift of the focus to the younger generation, the attempt to "extend the age of the participants" by emphasizing the contribution of the Home Front workers to the victory, changes in the exhibition at the Victory Museum on Moscow's Poklonnaya Gora, reflecting new accents in the "great narrative" of war, and new trends in visual propaganda. Special attention is paid to the transformation of the Immortal Regiment civil event which went online. The article shows a connection between the commemoration of the 75th anniversary of the Victory and the domestic political agenda, primarily constitutional amendments, and foreign policy context.
\end{abstract}

Keywords: memory politics in Russia, 75th anniversary of Victory in the Great Patriotic War, "Home Front labor feats," Immortal Regiment, memory wars.

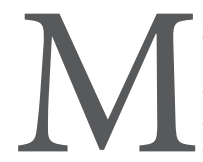

ajor celebrations are always momentous, but some are in a special way. The 75th anniversary of the end of World War veterans could take any significant part. The anniversary coincided with a period of increasing uncertainty in international relations, which also manifested itself in intensified politics of memory with regard to that war. The relative contribution of the anti-Hitler coalition states' to the victory has always spurred debates, but the causes of the war, its results and meaning, if you will, began to be debated with a vengeance precisely at a time when the world order established in Yalta and Potsdam had largely been destroyed and its key international institutions shaken. The main elements of the war narrative established by the victors in Nuremberg were questioned.

In this situation, the celebration of the anniversary of the Great Victory, which plays the role of the only "foundational myth" in 
modern Russia (since the Great October Socialist Revolution ceased to be such a myth with the collapse of the Soviet Union, and the three days of the "struggle for democracy" in August 1991 did not become a new myth), was to become a particularly significant and momentous event. Preparations began in advance (Decree \#327, 2019). Planned expenses can give us an idea about the scale of events dedicated to May 9, 2020. The Office of the President of the Russian Federation in 2019-2020 concluded five contracts, totaling almost half a billion rubles, to organize protocol events, an international press center and the reception of foreign guests (ClearSpending, 2020). Four of them were signed in March-May of this year. In other words, the Kremlin hoped till the last that the planned scenario could be implemented. However, all plans were ruined by the coronavirus epidemic, which not only forbade 60,000 living war veterans from public life but made any mass events in April and May impossible. The epidemic also messed up plans to intertwine growing expectations of the holiday with a nationwide referendum on constitutional amendments, initially scheduled April 22. This sequence had to be changed, with the parade on June 24 preceding the vote on July 1 . And yet, not incidentally, the two events remained closely connected.

This has created a complex and, at the same time, heuristically very productive situation for researchers of cultural memory and symbolic politics. We can assess the "response time," in other words, the ability of the authorities to adjust plans and adapt to an unusual situation. This, of course, does not rule out the analysis of the original plans, both implemented and canceled or delayed. We can also see unique social reactions to a situation in which most of the commemorative events have gone online, where the usual forms of commemoration and mobilization do not work. For the first time ever, we can observe an experimental gap between the sacred date of May 9 and the parade held on June 24, as well as the Immortal Regiment procession, which was rescheduled for July 26. The date of events marking the end of World War II has also been changed and set for September 3.

Naturally, a comprehensive analysis of the domestic and foreign policy aspects of the politics of war memory in the anniversary year 
will require the time and effort of many researchers, especially since events previously held close to May 9 have now been stretched in time to several months. But we consider it important to offer a kind of quick analysis, which covers precisely the "quarantine period" until the beginning of July 2020, and considers both the domestic and foreign policy aspects of the topic and their inter-relationship. We see our main task in creating a preliminary "map" of the research field, which can be used for further work.

The target audience of the Victory Day celebrations had changed completely by the 75th anniversary. At a meeting of the Victory Day Organizing Committee in 2018, Putin emphasized: "The torch [of memory line] is passing to the great-grandsons of the victors, and this memory must remain clean and unite the public" (Putin, 2018). The memory of the Great Patriotic War and the Victory expectedly occupied the central place in this program. The presentation, prepared by the Year of Remembrance and Glory Directorate in November 2019, named the patriotic education of young Russian citizens as the main task, which was not intended for just one anniversary year, but was expected to lay the foundation for a new system of patriotic education (Presentation, 2019). In May 2020, Putin amended the federal law on education, supplementing the concept of education with the need for students to develop a "sense of patriotism and civic virtue, respect for the memory of the defenders of the Fatherland" (Draft Law \#960545-7, 2020). Finally, on July 4, 2020, at a meeting of the working group on constitutional amendments, Putin supported the proposal to introduce "lessons of historical memory" in schools. L.V. Dudova of the Association of Teachers of Literature and the Russian Language, formulated her proposal as follows: "This year, such lessons were devoted to the 75th anniversary of the Victory, but our history is rich and diverse, and the more often we turn to our historical heritage, remind our pupils that they are the successors of the great history of a great country, the better. This is also a form of patriotic education. The State Duma has just passed amendments to the law on patriotic education. This is recorded in amendments to the Constitution of the Russian Federation. It seems we should think about and give instructions on how to make such events 


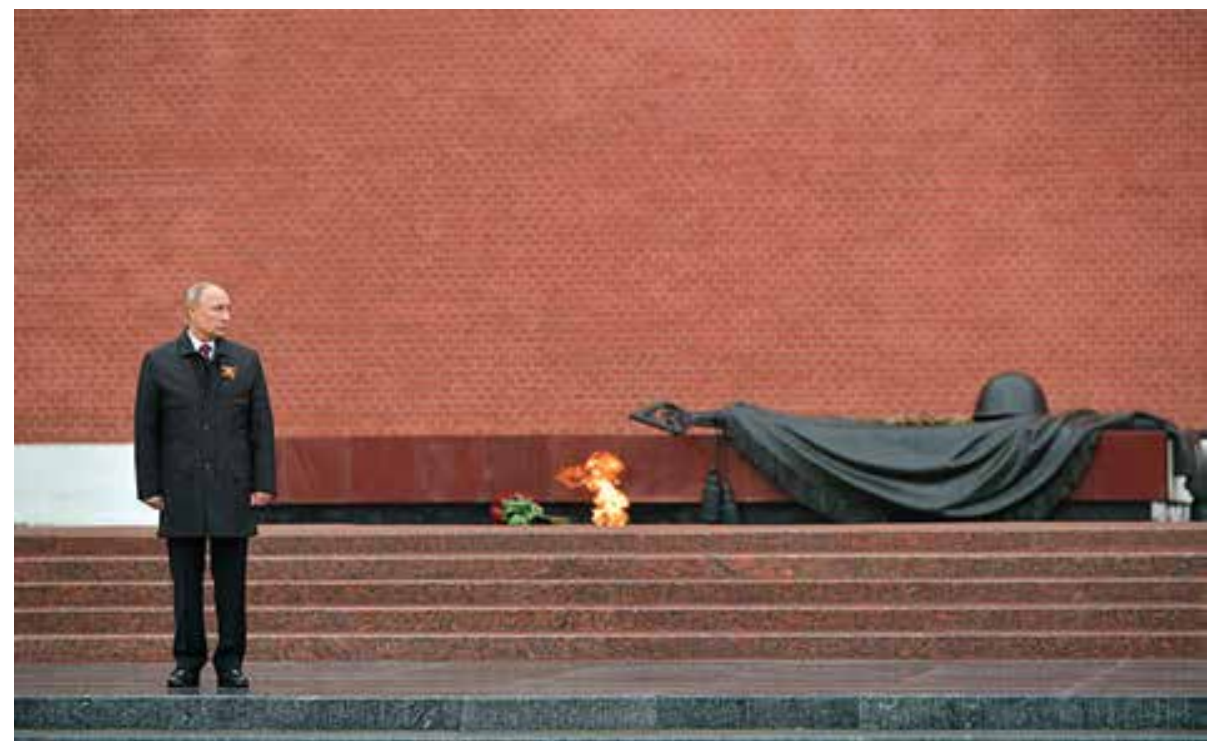

Vladimir Putin at the Tomb of the Unknown Soldier, May 9, 2020

kremlin.ru

regular in the work of not only general schools, but also secondary and higher education institutions. Historical memory needs to be invoked constantly" (Meeting, 2020).

At the same meeting on July 4, 2020, the working group approved a proposal to introduce Constitution lessons, which clearly showed that the question of constitutional amendments was intertwined with the anniversary of the Victory and historical memory. We will soon see what the new system of patriotic education, actively under construction since 2018, will look like. We will also see whether the authorities will try to turn the day the updated Constitution entered into force into a new holiday to supplement the foundational myth associated with the Great Victory with a new foundational myth-the adoption of an updated Constitution of "truly sovereign" Russia that has overcome the legacy of the turbulent 1990s.

The Year of Remembrance and Glory officially kicked off in December 2019 at the All-Russia Patriotic Forum. More than 10,000 patriotic activities and events were announced for the coming year, with young people to be actively involved in organizing and conducting them. Memory in these plans was perceived as an arena for struggle. 
"Historical memory is based on the refutation of falsifications," stated the priority guidelines approved by the Year of Remembrance and Glory Directorate (Presentation, 2019).

Fifteen central events of the year were expected to be attended by almost 159 million people, in addition to hundreds or maybe even thousands of regional and local events. Such attendance was planned for new projects only and did not include the participants in the Immortal Regiment processions, the most massive civil event of all.

However, the pandemic necessitated rapid changes in the approved celebration program. Some projects were suspended and some went online. Many new events were announced, often repeating each other, but pursuing one and the same goal-to fill the information field to the maximum, keeping the focus on May 9, and encourage people to demonstrate their engagement with the holiday on the Internet.

All told, by the end of June, seven of the 15 central projects of the Year of Remembrance and Glory had taken place or were in progress ("No Statute of Limitations," "Bread of the Siege," "For the Memory of Heroes," "Faces of Victory," "Victory Train," "Garden of Memory," and "Candle of Memory"). These are mainly long-term projects whereas events designed to consolidate emotional engagement and physical bonding among people could not be carried out (for example, reconstruction of the atmosphere of May 9, 1945 as part of the "Rio Rita-Joy of Victory" project, which was expected to bring together some 11 million people in one day, or mass singing of military songs at stadiums during football or hockey games). As quarantine restrictions are lifted, some key events are held but without much media coverage and on a smaller scale (for example, "Victory Train").

\section{IMMORTAL REGIMENT}

Shortly before May, the authorities had to give up the role of the principal architect of the holiday, and the Immortal Regiment, which was not among the 15 central projects of the year and soon went online, became a key federal event. The president did not participate in it. The portrait of his father was not uploaded to the Immortal Regiment's site, and his formal one-minute address to the partici- 
pants of the May 9 rally was recorded in a strikingly careless manner. Nevertheless, it was announced that Putin could take part in some events on May 9. At a meeting with Victory Volunteers, responding to the proposed mass performance of the "Victory Day" song on balconies, Putin said that he would "gladly do it," but, expectedly did not. On Victory Day, personified power had to withdraw from the center of public attention, which it had long been preparing for itself. The lonely figure of the president in the rain in Moscow's Alexander Garden vividly proved the point, while the inept camera work only emphasized the improvised nature of the event.

Some very interesting things happened to the Immortal Regiment, though. In the traditionally huge procession, individual portraits and the people carrying them merged into one whole (thus creating a strong sense of engagement). A festive procession of huge masses of people was impossible in May 2020. However, its online version turned out to be quite successful as it emphasized a different side of the Immortal Regiment and set new mechanisms in motion.

People were invited to join the project by uploading photos of their relatives and information about them to the Immortal Regiment website. In a short time, a lot of work was done, partners and sponsors were mobilized to engage the audience, an online platform was created, applications were integrated into Russian social networks, and thousands of volunteers were trained to manage applications. On May 9, the event was broadcast on almost 20,000 screens, in public transport, online cinemas, social networks, and on the Immortal Regiment's official website. According to the organizers, 2,392,199 heroes were registered in the online march, which was broadcast on the Internet for 19 days.

However, this year both the official agenda and personal interest focused on articulating family history (not only the names of heroes) and glorifying the feat of each person who fought in the war. The history of search queries in Yandex for similar periods of 2019 and 2020 shows that 601,625 search requests were registered in April-May 2019 for the "Feat of the People" website where one can find a huge array of data concerning the military service of soldiers and officers 
during the Great Patriotic War. In the same period of 2020, the number of such search requests increased almost twofold to 1,077,223.

The Immortal Regiment statistics are similar: 2,358,637 requests in 2019 and 4,265,649 in 2020. Moreover, search requests for both the Immortal Regiment and the "Feat of the People" portal were made in the Russian segment of the Internet regardless of May 9. In fact, in the first five months of 2020, search queries concerning the Immortal Regiment were registered five times more often than in the same period of last year.

Proceeding from these figures, it would be useful to find out why, where and in what forms this eagerness to look for information and preserve the family history of the war was expressed. Once created, the Immortal Regiment began to perform an important functionthe fallen heroes acquired names, which were remembered more and more often as May 9 approached. But at the same time, each hero remained nameless in the multimillion-strong procession, which grew over years to include not only more real heroes, but also many carnivalized, often inappropriate, images. Talking about the feat of each hero, separating him from a multimillion-strong procession, and publicly articulating family history were impossible in the regular Immortal Regiment format. The online mode became a catalyst for this new turn from preserving the name of a hero to preserving memory of him as part of family history. It is not surprising that in the online format the main audience expectedly decided against a fleeting appearance of its hero on virtual Red Square and opted instead for an unlimited, both in form and volume, narration where it could be heard, primarily in social networks. The number of publications telling family stories about the war on personal pages, especially on Facebook, where the official application of the Russian Immortal Regiment was not integrated, and in various self-organized Internet communities and groups, was much greater than in all of the previous years. Outside the Immortal Regiment physical procession, every hero became more noticeable and gained a personal history. By the year 2020 the Russian audience had clearly developed a willingness to explore and preserve this history. While before the memory of the 


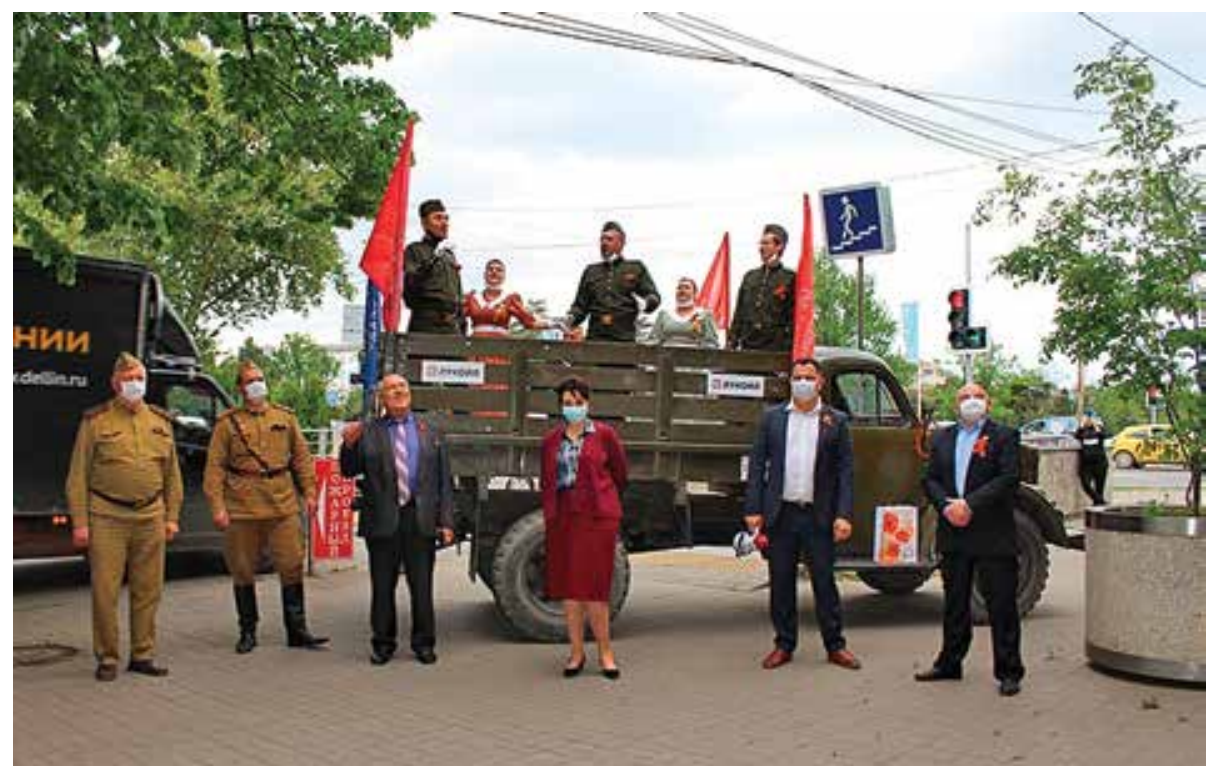

"Front-line concert" as part of Victory Day celebrations organized by Krasnodar city administration for Honorary Citizens under lockdown, May 9, 2020, krd.ru

war (tragic, painful and mostly silent) was kept inside family, mainly by living war veterans, now the threshold had been crossed and silent veneration of their feats or articulation of the names of fallen heroes was no longer enough. With fewer war veterans remaining alive and the Immortal Regiment establishing new practices of remembering heroes, the memory that had previously been tacitly revered in the family began to be talked about publicly.

The official politics of memory is developing in a similar way. It is evolving from the memory of unnamed acts of heroism into the memory of personal exploits and glorification of each individual story. Posters with the portraits of soldiers and their names on the streets of cities are the most vivid illustration of this trend. An example of a nationwide movement is the "In Memory of Heroes" project, whereby posters depicting war heroes and, importantly, Home Front workers, supplemented with QR codes and links to their personal stories, were installed in public places.

Concerts and sometimes parades under the windows of veterans' flats in residential areas are another, albeit more controversial, example, largely prompted by the desire of television channels to show each such 
performance in their news programs. Along with the personalization of memory, the official agenda also works with family memory, urging its keepers to share individual stories. This is vividly illustrated by the "Faces of Victory" project. Work is underway as part of this project to create a historical depository at Moscow's Victory Museum, featuring the names, photographs, dates of birth and death, and stories about "everyone who contributed to the Victory." The idea of a "popular" depository implies the creation of "a single space of historical memory that will unite residents of different countries as heirs to the common Victory" (Presentation, 2019).

The Immortal Regiment as a practice has indeed become the main form of remembrance of the war this year. However, in addition to the shift from one's name to one's personal history, both the format and the way of participation have expanded substantially, and the official agenda did not resist. In addition to the central procession on the Immortal Regiment's official website, hundreds of initiatives were launched to collect information for local "Regiments," with two forms being particularly distinctive: corporate and regional. The audience used those platforms where the family story could be not only told, but also heard by like-minded people. Businesses, media, budgetary institutions, professional communities, and interest groups gathered information about the family heroes of their members, thus turning this form of remembrance into a way of expressing corporate identity. While covering official online processions, regional television channels and newspapers also urged their audiences to share their family stories with the editors in order to build a local, urban or regional database of heroes. Universities, schools, libraries, government institutions, construction companies, and sports clubs created their own databases, which evokes memories of the well-known Soviet practice whereby the portraits and names of war veterans were placed on special billboards in institutions and organizations. However, today the focus is not on names but stories which can unite people into different "regiments" that do not correspond to the real fronts, regiments or detachments in which their ancestors fought but create different forms of identity. 
The Immortal Regiment has also become a platform for fighting the "enemies of memory." Hacker attacks and provocations against the Russian Immortal Regiment featured prominently on the information agenda associated with the Victory Day celebrations. This issue took up a significant part of the final news conference held by the organizers, who stressed the coordinated nature and the scale of the attacks that occurred on May 9. According to the announced data, $64 \%$ of the servers used in the DDOS attacks were located in European countries and 27\% in North America. Attacks also targeted the website of the "Victory Volunteers" project, whose participants helped process applications for the online march. It will not be possible to determine the actual scale and origin of the attacks, but the rhetoric of the besieged memory fortress was quite persistent.

Attacks on the memory of the war were also carried out inside Russia, not by means of DDOS attacks, but by means of provocations to add photographs of Nazi criminals or their collaborators to the Immortal Regiment database. Media reports about this came out on the same day as the news of hacker attacks, May 10, with new details and facts constantly added. While the first reports about Heinrich Himmler's photo that appeared during the online march ascribed the incident to "probably a mentally disturbed person" (RIA "Novosti," 2020a), four days later the Investigative Committee opened criminal cases for the rehabilitation of Nazism, since similar incidents had occurred during other events as well (for example, Adolf Hitler's photo was uploaded to the Bank of Memory). On the same day, numerous media publications reported that public figures, politicians and ordinary Russians were condemning the provocations, and on the following day the Investigative Committee announced that it had tracked down the provocateurs by their IP addresses. It said that most of the several dozen suspects were foreigners. Two days later, the homes of four suspects in different Russian regions were searched, and Investigative Committee spokesperson Svetlana Petrenko said that the perpetrators included citizens of Ukraine and Estonia (Kozlova, 2020). It was also claimed that the suspects were connected with oppositionist Alexei Navalny's regional headquarters. By June 4, five Russians had been charged with the rehabilitation of Nazism. 


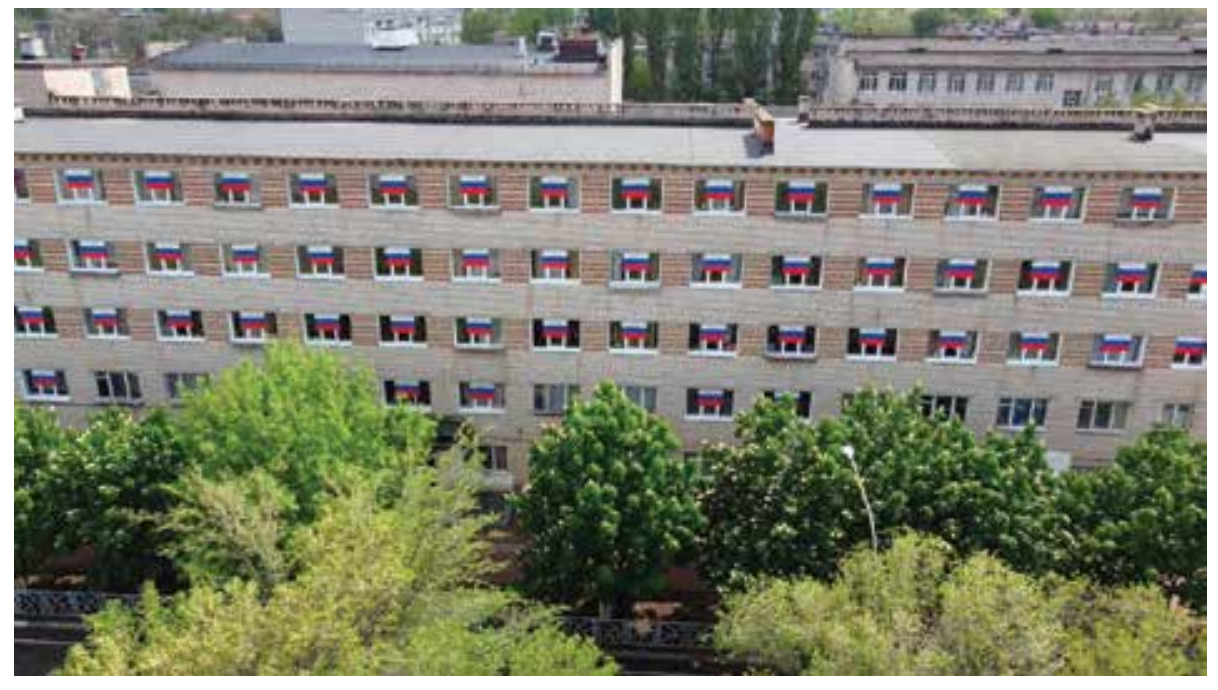

"Flag of Russia"Victory Day 2020 action in Nevinnomyssk, nevadm.ru

\section{VISUAL ASPECT}

All major Russian cities had to be decorated the same way for May 9. Necessary instructions had been sent to the regional and city administrations. The main color of the visual design was red, no tricolor in the official logo and no St. George ribbons were recommended. The ribbon was allowed as an "optional" element on posters or banners, linking, for example, the dates 1941 and 1945. It could also be added to the approved logo only as instructed or not added at all. The "Guide to the Use of the Logo for the Celebration of the 75th Anniversary of the Victory in the Great Patriotic War of 1941-1945" did not offer any options for the use of the logo with a ribbon, but allowed several ways of using it to match the overall holiday design pattern. There is a clarification in the description of additional elements of the composition: "It is necessary to adhere to this description when making non-standard layouts that are not considered in this Guide. In all other cases, it is recommended to use ready-made layout designs" (Brandbook, 2020). The logo for the 70th anniversary of the Victory contained both the tricolor and the ribbon, and also the dove as a symbol of peace.

In 2020, the St. George Ribbon initiative marked its 15th anniversary, but this symbol has obviously been used less than before. It could be seen 


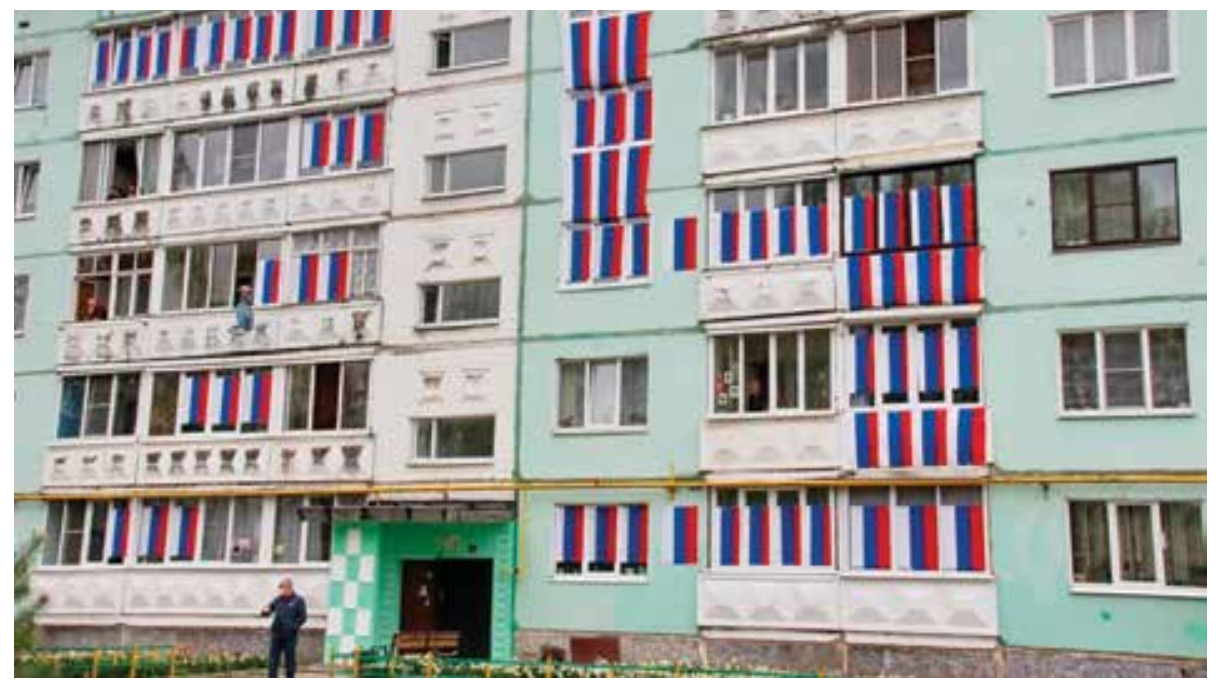

Window decoration forming number 75. "Flag of Russia" action in Ivanovo region,

on the president's chest and on the standards carried during the Russian Immortal Regiment online procession. But on May 9 of this year, the heads of some regions did not wear the ribbon on their lapels.

The online format did not allow the carefully designed visual elements of the celebration to be used in full, and the flags and banners with the words "May 9" printed on them, often looked quite phantasmagorical in June. With the self-isolation regime still in effect, the authorities decided to move festive decorations from central squares and streets to residential areas and hastily announced events designed to demonstrate the patriotic unity of Russians around the holiday during the lockdown. The "Flags of Russia. May 9," co-organized by United Russia, was one of them. The idea was that Russians would hang out national flags with the St. George ribbons in windows and balconies of their home. But in large cities, the effect was not as visible as in regional cities, where the administrations did their job with greater responsibility. Whole yards were decorated uniformly with tricolors (without ribbons), which looked surreal in the deserted streets during the lockdown. Visually, on May 9 a provincial Russian city turned into a rehearsal of Day of Russia celebrations, so ideal for the authorities, except that there were no Russians themselves. (But the tradition of 


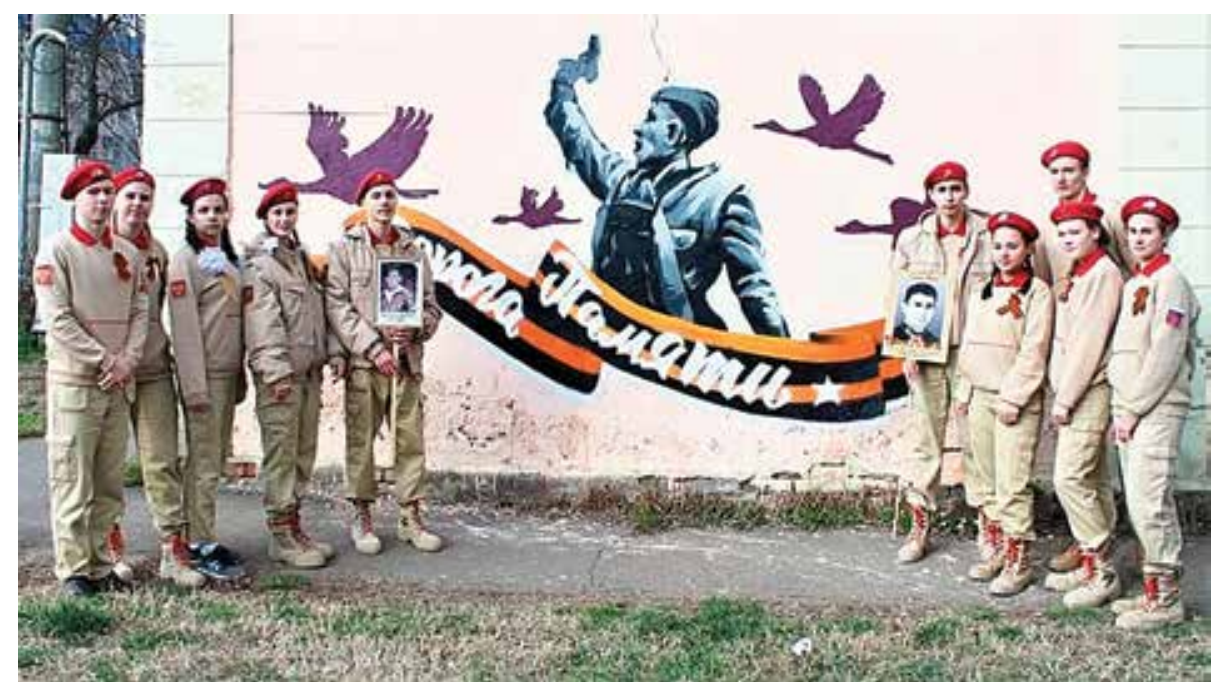

Members of the "Youth Army" patriotic movement at their own made "The Road of Memory" graffiti in Krasnodar, krd.ru

marking a holiday without people seems to have been established by Putin's inauguration in 2012). Flags were sent out to the regional administrations, including by the Year of Remembrance and Glory Directorate, and were then distributed among municipalities. In early June, it was announced that the rehearsed May 9 procedure would be repeated during Day of Russia celebrations.

In general, it can be concluded that the struggle for the colors of the Victory Day holiday, started with the appearance of the St. George ribbon, is over. While at the time of its "invention" the ribbon was intended to replace red color and communist symbols, now the red Banner of Victory, the St. George ribbon, and the national tricolor flag peacefully coexist in the visual design of the holiday.

With the "color conflict" settled, the official Russian politics of memory has outlined another area of work, namely, attempts to find new visual forms for communication with the younger generation. Since young people were the new target audience for the Victory Day celebrations, the official agenda turned to forms close to this audience, in particular, graffiti. For example, a contest of graffiti sketches was announced to depict the marshals of Victory and the heroes of the Second World War, called "Bright Victory." There are 


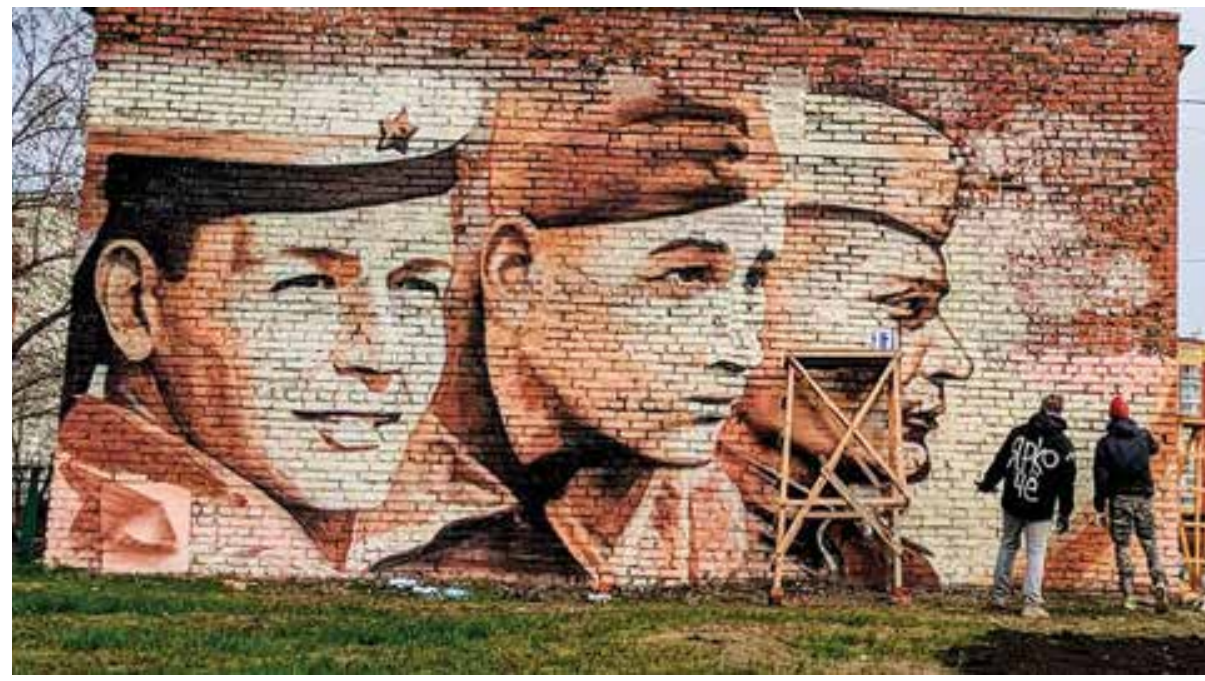

"Victory" graffiti in Omsk (made in 2018), omskzdes.ru

many other similar initiatives put forth by different agencies and organizations, most of which are timed to coincide with the Year of Remembrance and Glory. The "Portrait of Memory" program has been in progress since 2018; young people have been showing their street art skills as part of the "Road of Memory" project; in some regions graffiti contests are financed by local administrations, private sponsors, and large companies (for example, Rosseti sponsored a graffiti in Voronezh). Obviously, the official authorities are just beginning to master these new forms.

\section{VISUAL MONUMENTALITY. CHURCH AND MUSEUM}

The general public learned about the completion of the construction of the Main Cathedral of the Armed Forces, or the Church of the Ascension of Christ, in the Patriot Park in Kubinka near Moscow from media reports which said that the church had a mosaic depicting Putin and his closest associates at the time of triumph after the reincorporation of Crimea into Russia. Another mosaic depicted a parade on Red Square, with a portrait of Stalin hanging above it (Dzhordzhevich, 2020). So the issue of whether Stalin's images were permissible or inappropriate and of his role in the war, a traditional 


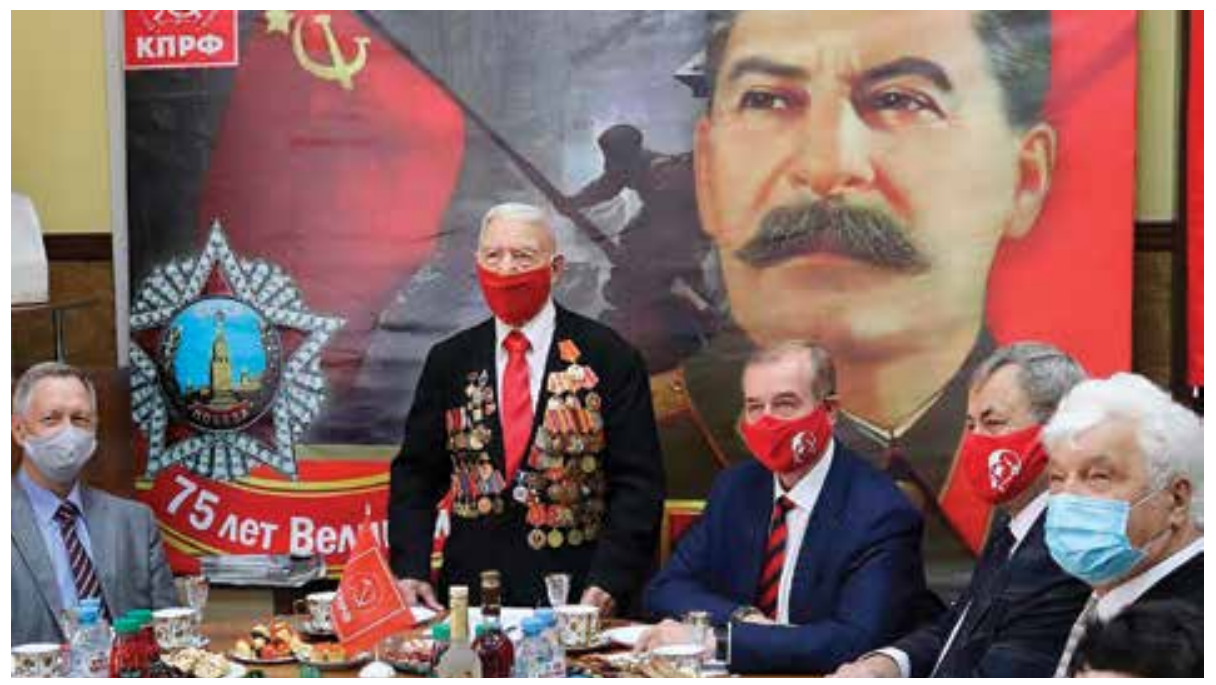

Ceremonial meeting of the Council of Elders of the CPRF Committee in Irkutsk, regnum.ru

theme for the Victory Day holiday, hit the headlines, but it was clear that this time it was not a mainstream topic. Actually, it was completely peripheral for the authorities, because Putin's remarks that the mosaic with his image was out of place were enough for both pieces to disappear from the cathedral. The most striking appearance of Stalin's image in the media was a publication by a former governor of the Irkutsk region and the head of the Irkutsk regional committee of the Russian Communist Party, Sergei Levchenko, with photographs of the party's "Council of Elders" ahead of May 9, including WWII veterans, and a banner bearing a portrait of Stalin on the wall behind them (Regnum, 2020). It only emphasized the marginal character of the Stalin theme as the "Father of Victory" and the peripheral role of the Communist Party in anniversary events.

The opening of the cathedral, filled with numerical symbols associated with the Great Patriotic War, and a museum as part of one whole was scheduled for May 5, and was expected to become the most important part of the preparations for Victory Day celebrations. This was supposed to emphasize the post-secular character of the memory of war. During the consecration of the church on June 15, Patriarch Kirill announced that he was assuming the role of its arch-priest. However, the 
analysis of the artistic aspects of the cathedral and its symbolism goes beyond the scope of this article. This is a very broad topic. Let us just note one thing that has not yet been mentioned in numerous comments about the cathedral. It is quite obvious that the style of the cathedral echoes the "Russian style" of the Church of the Assumption of the Blessed Virgin Mary in St. Petersburg, built at the end of the 19th century, where the parents of Patriarch Kirill, who has become the arch-priest of the new cathedral outside Moscow, met in the church choir.

Another important place is the Victory Museum on Moscow's Poklonnaya Gora, not new, but radically renovated for the occasion and officially declared the central museum of the celebrations. It took more than a year and 500 million rubles to build its new exposition, occupying 3,000 square meters and titled "The Feat of the People." The exposition clearly indicates a major shift in the official narrative of war, more precisely, changes in the degree of attention paid to various topics. One can say quite confidently that these changes will be reflected both in the expositions of other museums across the country and in the great narrative of war (Pobeda.rf, 2020).

The biggest part of the new exposition is devoted to the labor feat on the Home Front, and its goal is to show that "all the people, even those who did not take up arms, tried to do everything possible to defeat the enemy" (Victory Museum, 2020). The refocusing of attention to the Home Front and its contribution to the victory is a key new element that performs an important function of extending "living memory." The feat in official discourse is becoming more popular and all-encompassing.

The topic of heroism is interlaced quite closely not only with the names of front-line soldiers, but also with those whose contribution was previously mentioned in passing. In March 2020, Putin signed a law introducing the "City of Labor Valor" title (Law \#41-FZ, 2020). Similar draft laws giving the honorary title of the city of labor or military-labor glory were submitted to the State Duma several times over the past ten years but were always shelved. However, in December 2019, Putin himself submitted a draft law, replacing the word "glory," which was reserved for military exploits, with the word 
"valor." Many regions are now preparing documents for winning this title for their cities. The adoption of the law strongly influenced the rhetoric of the regional authorities with regard to Victory Day celebrations this year and provided the basis for building local narratives about "mass labor heroism and selflessness" across the country, especially in those regions where no actual fighting took place. On July 2, at a meeting of the Victory Organizing Committee, Putin awarded the title of "City of Labor Valor" to the first 20 cities. An important argument in favor of nine of them was the number of signatures collected by its residents in their support (Putin, 2020a). The campaign to collect signatures ended simultaneously with the vote for constitutional amendments.

As the living memory of the war is increasingly fading, it has become necessary to extend the age of the heroes. The engagement of young people in the remembrance of the war was accompanied by greater attention to the children of war, that is, those who did not fight on the front lines, but whose childhood coincided with the war years. For example, the "My Childhood is War" contest lasted from February 15 to August 15. Its participants were invited to write articles about the children of war for Wikipedia. According to the organizers, more than 2,000 articles had been published by June.

The leitmotif of the Year of Remembrance and Glory was the glorification of the feat not only of those who fought on the front lines or those who worked on the Home Front, but of everyone "whose daily life during the war became a feat." The concept of heroism expanded to the limits where literally, not just figuratively, every Russian schoolboy could find something heroic in his family past and publicly tell the story of his hero/heroes in one or better still in several of the hundreds of nationwide or local events launched specially for this purpose. This topic was explored further by opening a large ("biggest in the world") Home Front museum called the "Battle for the Weapons of the Great Victory" at the Prokhorovka memorial complex in the Belgorod region. By placing the emphasis on the contribution to the Victory made by teenagers and even five-year-old children who put soft pads into helmets made for soldiers, the authorities have reaffirmed their 


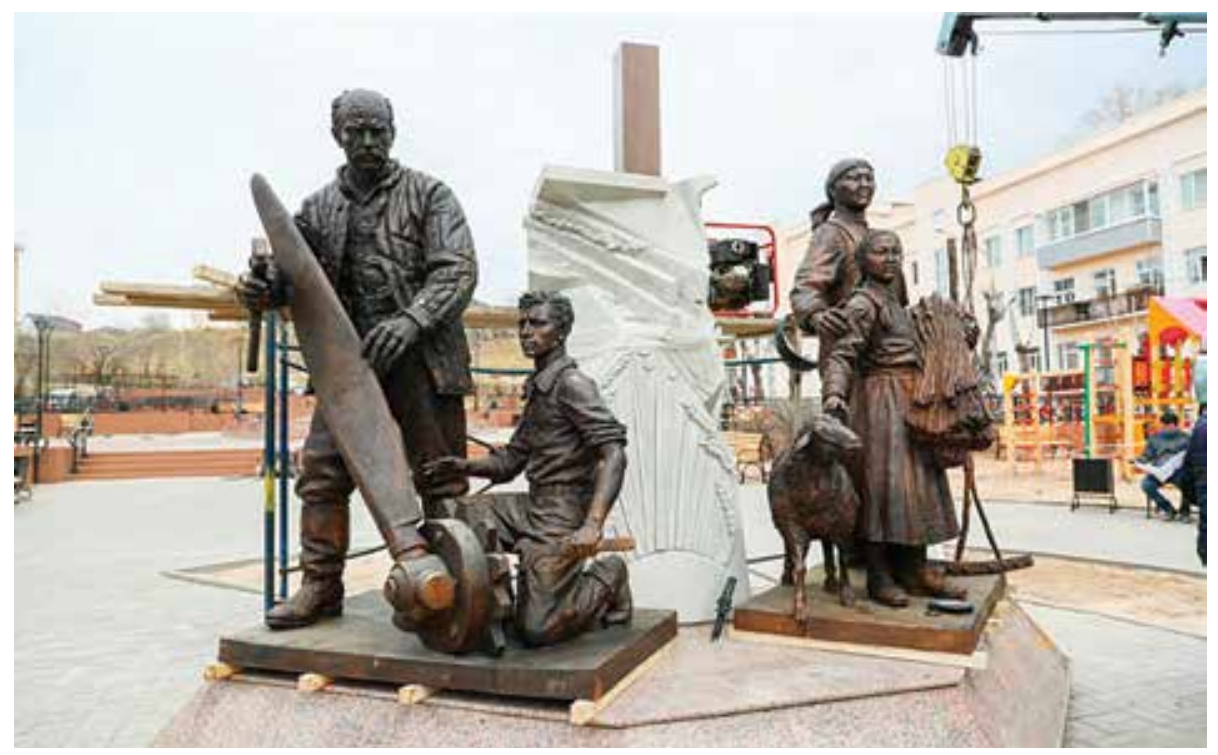

Monument to Homefront Workers and Children of War on the Square of Glory in Ulan-Ude,

blogrb.ru

determination to "extend the age" of those who made the victory possible (Zachepa, 2020).

An example is a monument unveiled in Ulan-Ude on the eve of May 9, which commemorated Home Front workers and war children. It depicts a man and a boy of European appearance with tools standing by the aircraft propeller, on one side, and a woman and an Asian girl with a sheaf of rye, sheep, and a rake, on the other side. The monument evoked a controversial reaction in Buryatia. Other monuments to the Home Front heroes have been unveiled throughout the year in large Russian cities, in district capitals, and at individual enterprises. The campaign for commemorating the labor feat of Home Front workers, which started about ten years ago, and war children received a new impetus this year, and we still have to see its fruits.

In addition to science, medicine, evacuation, and other expected topics, the "Feat of the People" exhibition also includes two more sections that deserve special attention and illustrate trends that are important for the Russian politics of memory.

The penultimate section of the exhibition is called "The Liberation of Europe." It emphasizes the fact that "the Soviet Union, starving 
and struggling with the aftermath of the occupation, fed, helped and provided medical aid to residents of countries that participated in the war on the side of the invaders" (Victory Museum, 2020). In the wars of memory, where Russia, as the successor of the USSR, is equated with Nazi Germany and "Soviet occupation replaces the German one," the official Russian narrative emphasizes the feat of the starving people who had suffered at the hands of the invaders and who came to the rescue of the peoples of devastated Europe, even those whose countries had fought against the USSR.

The section devoted to the liberation of Europe is preceded by a section called "Veliky Novgorod," which serves as a local illustration of Nazi crimes in the occupied Soviet territories. This section indicates a new attention to the sufferings experienced by the Russian people. One of the central events of the Year of Remembrance and Glory is the project "No Statute of Limitations," implemented jointly by many agencies and organizations in order to preserve the memory of the Soviet victims of Nazi war crimes. The Novgorod region was the place where the search for evidence started. Russia's historical policy is persistently mobilizing all available resources in order to emphasize its status as a victim of Nazism and expose the role of Nazi collaborators. Since 2019, different government agencies have declassified hundreds of documents about previously unknown or insufficiently publicized crimes committed not only by the Nazis, but primarily by their accomplices in the Baltic states and Ukraine. In Soviet times, these facts were glossed over so as not to spoil relations in the family of Soviet peoples. In parallel, the search is underway and relevant exhibitions are opening in 50 regions as planned ("No Statute of Limitations" is an educational project). Work is in progress to prepare conferences and the publication of a 23-volume collection of materials and documents; documents are being digitized and made available to the general public. Students are engaged in this work as part of the Archival Landing Party campaign under the auspices of the Search Movement of Russia.

In addition to preserving the memory of the victims, this ambitious project also implies the prosecution of living participants 
in those crimes. The project roadmap formulates the task for MarchOctober 2020 as follows: "Conducting search expeditions, initiating criminal cases under the charges of genocide in 22 constituent entities of the Russian Federation" (Presentation, 2019). A special portal has been created where documents on the crimes committed by the Nazis and pertinent comments are posted (see Dyukov, 2020; RIA Novosti, 2019a; RIA Novosti, 2019b; Pobeda.rf, 2020b; RIA Novosti, 2020b; RIA Novosti, 2020c). The Investigative Committee has announced a number of new investigations into Nazi crimes (Bastrykin, 2020).

In addition to major memorial complexes inaugurated before, on June 30, the presidents of Russia and Belarus jointly unveiled a colossal monument to the Soviet soldier near Rzhev in the Tver region, where more than a million Red Army soldiers had been killed in a series of battles during World War II (Kremlin, 2020; Kolesnikov, 2020). A large museum complex "Sambek Heights" is to be opened near Taganrog where the 416th Azerbaijani Division fought during the war. So we may see a duet of Russian and Azerbaijani presidents at the opening ceremony.

\section{TRAGEDIES AND EPICS}

Obviously, the motif of suffering and victimization will be emphasized not only by museum exhibitions. A film entitled "Passions for Zoya" is expected to be released in 2020 not only in Russia, but also in Europe. It expressly implies martyrdom as the central leitmotif and its Christian interpretation. There is no doubt that a tragic theme will also permeate another major project—the film "Nuremberg" (the second name is "Forever and Ever"). Presidential aide and former Minister of Culture Vladimir Medinsky proposed making its premiere the central film project devoted to the 75th anniversary of the Victory. Work on the "political thriller," which was expected to come as a response to the Americans who write "about Nuremberg as their big victory" (Medinsky, 2018), started in 2016 and was supposed to get budget funding for two years as a socially significant cultural and educational event, according to the action plan for the Year of Remembrance and Glory approved in 2018. On May 15 of this year, it became known 


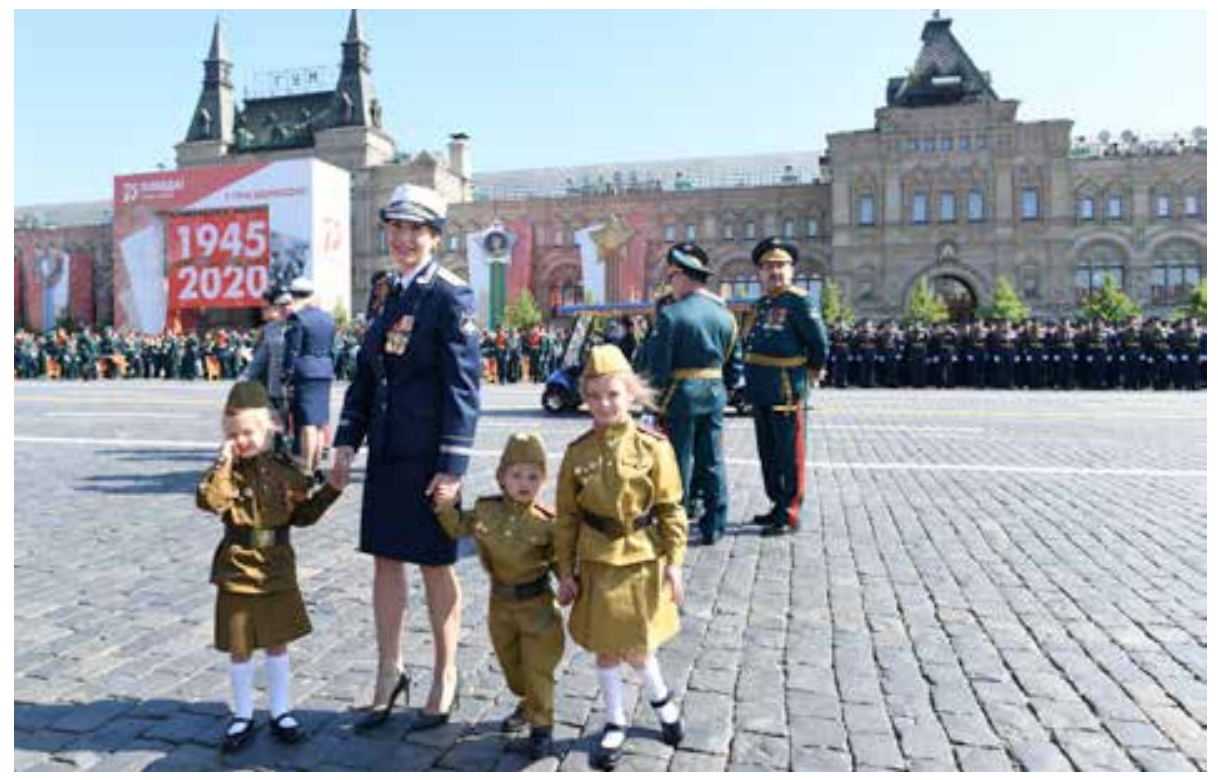

In anticipation of Victory Parade on Moscow's Red Square, June 24, 2020. photo.may9.ru

that the director of the film had changed, and the shooting had been postponed "due to the spread of coronavirus infection" (Uskov, 2020). As of August 1, 2019, the film had received budget funding in the amount of 245 million rubles.

Cinema clearly demonstrates another important trend in the memory of war, namely, its "epicization." Films like "T-34" and a variety of other productions about time travelers, which obviously do not seek to convey historical authenticity, already prevail among films about the war. This resonates with the latest fashion to dress children in war-era uniform. Side caps and other accessories are now available in supermarkets. One Facebook user, responding to the criticism of a photo showing his child wearing such uniform, noted that he did not see any difference between dressing a child in war-era uniform and a knight's armor; in both cases, the child fights the dragon and wins. It will be interesting to see in the future how the tendency to personalize memory and attempts to establish an emotional connection between young people and the memory of war through tragic motives will go along with the growing epicization of the memory of war. 


\section{FOREIGN POLICY ASPECT}

A detailed analysis of the foreign policy dimension of Russia's memory politics in the year of the 75th anniversary of the Victory is beyond the scope of this article. We will address this issue insomuch as may be necessary to adequately describe certain aspects of domestic commemorative events in Russia.

The foreign policy situation was sharply aggravated on the eve of the anniversary year by a European Parliament resolution titled "Importance of European Remembrance for the Future of Europe," adopted on September 18, 2019. It refers to the transgressions of different countries in working with the past, but only Russia is named specifically. It urges Russia to repent for the fact that Soviet totalitarianism and Nazi totalitarianism started World War II. The resolution consistently reproduced the narrative of two totalitarianisms that Eastern Europe countries had been advancing for many years. According to this narrative, Russia is not the successor of the USSR which made a decisive contribution to the victory over Nazism, but the successor of the USSR which, together with Nazi Germany, unleashed World War II, and therefore bears full responsibility for all its horrors. The resolution does not compare the Soviet and Nazi regimes but equalizes them as an embodiment of evil. The European Parliament adopted the resolution by an overwhelming majority, thus legitimizing this narrative across Europe. No European leader spoke critically of this resolution until December 20, 2019, when Vladimir Putin delivered an hour-long speech at a meeting with CIS leaders, which was soon called "lectures on history" (Putin, 2019). Written in extremely harsh terms, Putin's speech emphasized the responsibility of the leaders of France and Britain for the policy of pacifying Hitler and signing the Munich Agreement. But the main blow was directed at Poland, whose deputies had initiated the EP September resolution. Putin stressed the anti-Semitism of the prewar Polish leadership and the role of Poland in the partitioning of Czechoslovakia, as well as its responsibility for undermining the Soviet Union's efforts to create a collective security system (Putin, 2019). At the end of his speech, Putin promised to personally write 
an article on the period leading up to the war. The decision of the Russian leader to join in the memory war caused a controversial reaction (see Miller, 2020a), but his speech clearly indicated that Putin considered the current direction of the politics of memory in Europe a serious enough threat to Russia to address the issue personally.

The first important symbolic date of the current year was the 75th anniversary of the liberation of the Auschwitz-Birkenau concentration camp (Auschwitz), which became a symbol of the Holocaust. A joint statement made by European Commission President Ursula von der Leyen, European Council President Charles Michel and European Parliament Speaker David Sassoli on January 23, 2020, on the eve of the anniversary, begins with the following words: "Seventy-five years ago, Allied Forces liberated the Nazi concentration camp AuschwitzBirkenau. They ended the most abhorrent crime in European history, the planned annihilation of the Jews in Europe" (Michel, Sassoli and von der Leyen, 2020). The statement never mentioned the fact that it was the Red Army that had stopped this most abhorrent of crimes. There were also many other publications and statements that logically prompted the conclusion that the Red Army could only do bad things (see Miller, 2020b).

Putin was not invited to commemorative events at Auschwitz. But the 75th anniversary of its liberation was also marked at Jerusalem's Yad Vashem. A monument to the victims of the Siege of Leningrad was unveiled as part of the ceremony. The tone of Putin's speech in Jerusalem was strikingly different from that of his December remarks. He emphasized the need for a mutually respectful dialogue on controversial issues in the history of the war, and invited the permanent members of the Security Council, that is, the victorious powers of World War II, to participate in this dialogue. His criticism of Poland and the Baltic countries was minimal.

The pandemic ruined the Kremlin's plans to turn May 9 into an international event. However, as usual, world leaders made statements on this occasion on the eve of the holiday. Most attention was traditionally grabbed by Donald Trump's tweet, in which he simply did 
not bother to mention the USSR among the powers that had defeated Hitler. However, a much more significant document was a declaration signed on May 7 by U.S. Secretary of State Michael Pompeo and the foreign ministers of nine NATO members of Central and Eastern Europe (Eurasia News, 2020). The declaration condemned "Russia's attempts to falsify history." Only the first paragraph mentioned the war, while the rest of the document focused on the occupation of the Baltic republics, and on the fact that after the war those countries that fell into Soviet captivity "remained under the rule of communist regimes" for decades by means of "military force, repression, and ideological control." The declaration, firstly, consolidated the United States' role as the main sponsor of the politics of memory pursued by the countries of "young Europe." The principle of dividing Europe into young and old, proposed by Donald Rumsfeld ahead of the invasion of Iraq, was invoked once again. Secondly, the declaration clearly defined the main frames: the focus from the war and the role of the Red Army in the defeat of Germany and Japan was shifted to the "post-war occupation," which ended only when these countries joined the free world. In other words, it is now clear that the memory war, whereby the countries of Eastern Europe attack Russia with the support of the United States and a significant part of the Western European establishment, will continue for many years to come.

On June 19, Putin published his promised article on history (Putin, 2020b). The quality of the text itself and its translation into English, and how and where this article was published raises many questions. But this is not very important in the context of our article. What is important is that Putin's article has become a kind of declaration of intent with regard to memory politics in the international arena. Firstly, Putin insisted that the causes of the war should not be reduced to the Soviet-German pact of August 1939, that this is a complex set of events and processes for which many countries should bear their share of responsibility. Secondly, he contested the assessment of the Baltic states' incorporation into the USSR as "occupation." Thirdly, he cited Soviet losses and German losses on the Eastern Front, thus emphasizing the decisive role of the USSR in the defeat of Germany. Finally, he quoted 


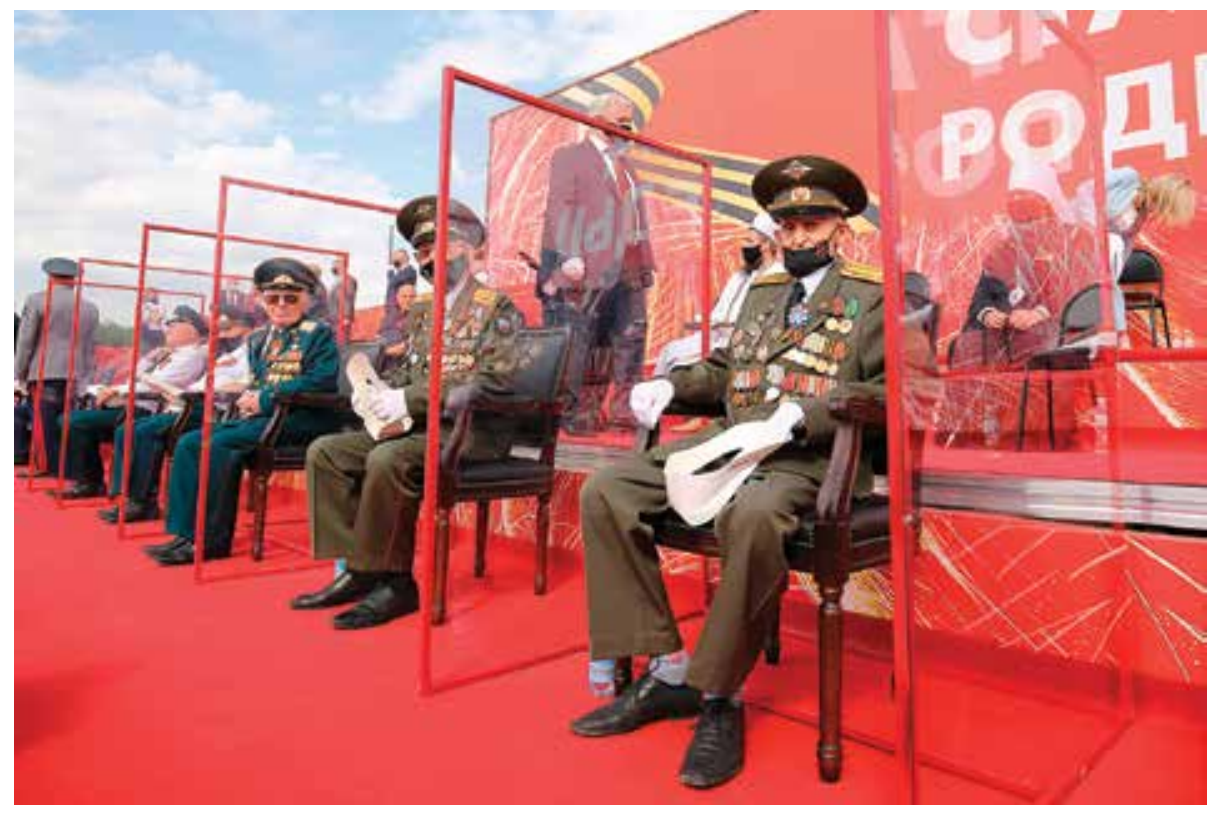

Veterans of the Great Patriotic War during Victory Parade in Volgograd, June 24, 2020. photo.may9.ru

documents on Soviet assistance to the population of the countries liberated by the Red Army in 1944-1945, thus challenging the claims of Soviet occupation. In general, he sketched the line of confrontation over all key points of the new stage of the war of memory. At the same time, the style was reserved, and Putin repeated his invitation to the permanent members of the UN Security Council to start a dialogue, declared the opening of archives, and suggested leaving controversial issues for professional historians to resolve. The article was obviously addressed to the countries of "old Europe" and the United States over the heads of Eastern European nations.

A number of steps in the domestic politics of war memory can only be understood by taking into account this foreign policy context. The motif of "protecting memory" from abuse and distortion by hostile forces abroad and their accomplices inside the country was also actively exploited as part of efforts designed to promote constitutional amendments. A special hall in the Victory Museum is devoted to Soviet assistance to the population of liberated countries, even those that were Hitler's allies. The emphasis on themes and 
images intended to show the tragedy of the Soviet people and their suffering during the war should lead people abroad to reject the "legend of two totalitarianisms."

Obviously, exhibitions of declassified archival documents and online access to documents of the 1930s "exposing the policy of pacification of Germany from the moment the Nazis came to power until the German attack on Poland" (Yeltsin Library, 2020), a project implemented jointly by the Federal Archival Agency, the Foreign Ministry, the Federal Security Service, the Defense Ministry, and the Foreign Intelligence Service, are addressed primarily to an international audience. Archival documents are also used to open cases against the few living participants in Nazi crimes. This policy has changed dramatically since Soviet times. While in the USSR the participation of Ukrainians, Lithuanians, and Latvians in Nazi crimes was concealed, now they will be accentuated. Russian archives have ample documented evidence of such crimes. The graphic presentation of these crimes, more and more often cited in the media, correlates quite well with the rehabilitation of Nazism in some countries of Eastern Europe.

The project "Remembrance, Research and Justice: Heritage of WWII in the 21st Century" (remembrance.ru), launched at the Russian State University for the Humanities, is targeted mainly at foreign audiences. It can be assumed that the principal operator of the project, presented as the result of cooperation between several NGOs, is the Historical Memory Foundation, which has proved to be one of the most effective Russian tools of memory wars since 2007. The project focuses on Nazi crimes in the USSR during the war and the glorification of Nazi criminals in neighboring countries, as well as political maneuvers of various countries on the eve of the war.

The Russian Investigative Committee is also working to create a legal basis for foreign policy steps. On July 9, the Investigative Committee initiated criminal proceedings under Article 357 of the Russian Criminal Code (genocide) "on charges of mass killings of civilians in the territory of the Stalingrad region (now Volgograd region) during the war by German troops and their accomplices." 
This case may potentially cause repercussions since the offensive on Stalingrad involved not only German troops, but also Italian and Romanian units (Yushkov, 2020).

Commemorative events of the anniversary year are still far from completion. However, some conclusions can already be made. The Great Victory as the foundational myth of the Russian state is inextricably interconnected with key issues of the country's current domestic and foreign policy. Despite the pandemic that upset the original scenario, the authorities have managed to intertwine the theme of Victory with the theme of an updated constitution. Not only did the anniversary of the Victory, but also the actively exploited theme of the "turbulent 1990s" lend a historical dimension to the constitutional amendments. It is no coincidence that there is intensive discussion on a possible transfer of Russia Day from July 12, when Yeltsin's Constitution was adopted, to July 1, when the final vote for its new, "Putin's" version was held. It can be assumed that the authorities will gradually build a narrative in which the amended Constitution will be presented as a final departure from the legacy of the "time of trouble" and as a new moment of "foundation," supplementing the Victory myth.

In terms of foreign policy, the appeal to the Soviet Union's role in the war continues to be an important argument in the dispute over the status of Russia as a great power, which appears to be quite apposite at a time when the world order is being reshaped. It is obvious that the Kremlin is trying to diversify the range of means by which it can defend its position in memory wars. This provides an insight into why the heroic component of the memory of war has been so vigorously complemented with the tragic component, which was not emphasized in relations with the collective West before the crisis. The memory of war is also used in relations with CIS and Eurasian countries which are actively nationalizing the memory of World War II (the Victory Parade held by Belarusian leader Alexander Lukashenko on May 9 in Minsk demonstrated his readiness to continue Soviet-era "big style" Victory commemorations), but these processes require a separate analysis. 


\section{References}

Bastrykin, A., 2020. Aleksandr Bastrykin: "Neizvestnyh prestupleniī natsistov estchyo ochen' mnogo" [Alexander Bastrykin: "Lots of Nazi Crimes Still Remain Unknown]. RIA Novosti, 03 July [online]. Available at: <https://ria. $\mathrm{ru} / 20200703 / 1573843867 . h t m l$ ?fbclid=IwAR3GHEMw_iPmNFTD0LU8Y0cxvV66DHTcmkWf-y83_zlj8Wkq0czEw2QvHE> [Accessed 06 July 2020].

Brandbook, 2020. Rukovodstvo po ispol'zovaniyu logotipa prazdnovaniya 75-ī godovstchiny Pobedy $v$ Velikoì Otechestvennoì voine 1941-1945 godov [Guide to the Use of the Logo for the Celebration of the 75th Anniversary of the Victory in the Great Patriotic War of 1941-1945]. Organizing Committee on the Celebration of the 75th Anniversary of the Victory in the Great Patriotic War of 1941-1945 [online]. Available at: <https://www.may9.ru/brandbook/> [Accessed 29 June 2020].

ClearSpending, 2020. Portal obshchestvennogo monitoringa goszakupok "GosZatraty" ["Goszatraty" Government Procurement Public Monitoring Portal]. Available at: <https://clearspending.ru/> [Accessed 04 June 2020].

Decree \#327, 2019. Ukaz Prezidenta Rossī̄skoī Federatsii ot 08.07.2019 goda. “O provedenii $v$ Rossīskoī Federatsii Goda pamyati i slavy" [Decree of the President of the Russian Federation of July 8, 2020. "On the Year of Remembrance and Glory in the Russian Federation"].

Draft Law \#960545-7, 2020. Zakonopoekt 960545-7. “O vnesenii izmenenī̄ v Federal'nyī zakon 'Ob obrazovanii v Rossīskoī Federatsii' po voprosam vospitaniya obuchayushchihsya” [Draft Law \#960545-7. “On Amendments to the Federal Law 'On Education in the Russian Federation' Regarding the Upbringing of Students"].

Dyukov, A., 2020. International Legal Basis for the Prosecution of Nazi War Criminals. Remembrance, Research \& Justice, 02 May [online]. Available at: $<$ https://eng.remembrance.ru/2020/05/02/international-legal-basis-for-theprosecution-of-nazi-war-criminals/> [Accessed 30 June 2020].

Dzhordzhevich, A., 2020. Izobrazheny rukovoditeli nashego gosudarstva, $v$ tom chisle sredi naroda [Our State Leaders Are Now Depicted among Ordinary Folk]. Novaya gazeta, 27 April [online]. Available at: <https://novayagazeta.ru/ articles/2020/04/24/85085-izobrazheny-rukovoditeli-nashego-gosudarstva-vtom-chisle-sredi-naroda> [Accessed 01 July 2020]. 
Eurasia News, 2020. The U.S. along with 9 NATO Friendly Countries Contested WWII History Told by Russia. Eurasia News, 08 May [online]. Available at: $<$ https://www.dispatchnewsdesk.com/us-along-with-9-nato-friendly-countriescontested-wwii-history-told-by-russia/> [Accessed 29 June 2020].

Kolesnikov, A., 2020. Nad propast'yu vo Rzheve [A Catcher in Rzhev]. Kommersant, 30 June [online]. Available at: <https://www.kommersant.ru/ doc/4398644?fbclid=IwAR0wRhVbTQ2cKB8z4E_Od7T8Pm6P0L7nLrUJb605hbVsDmHlIsTpaX3lrg> [Accessed 06 July 2020].

Kozlova, N., 2020. SK nazval prichastnyh k provokatsii v hode "Bessmertnogo polka" [The Investigation Committee Has Named Those Involved in the Provocation during the "Immortal Regiment" Online March]. Rossiīskaya gazeta, 16 May [online]. Available at: <https://rg.ru/2020/05/16/reg-pfo/sknazval-prichastnyh-k-provokacii-v-hode-bessmertnogo-polka.html $>$ [Accessed 29 June 2020].

Kremlin, 2020. Unveiling of the Rzhev Memorial to the Soviet Soldier. Official website of the President of the Russian Federation, 30 June [online]. Available at: <http://en.kremlin.ru/events/president/news/63585> [Accessed 06 July 2020].

Law \#41-FZ, 2020. Federal'ny zakon No. 41-FZ ot 1 marta 2020 goda "O pochyotnom zvanii Rossī̄skoī Federatsii 'Gorod trudovoī slavy"' [Federal Law \#41-FZ as of March 1, 2020 "On the Honorary Title of the Russian Federation 'City of Labor Valor"'].

Medinsky, V., 2018. Speech at the Meeting of the Pobeda (Victory) Organizing Committee. Official website of the President of the Russian Federation, 12 December [online]. Available at: <http://kremlin.ru/events/president/ news/59388> [Accessed 29 June 2020].

Meeting, 2020. Vstrecha s rabocheī gruppoī po podgotovke predlozhenīi o vnesenii popravok v Konstitutsiyu [Meeting with the Working Group on Drafting Proposals for Amendments to the Constitution. Transcript]. Official website of the President of thew Russian Federation, 03 July [online]. Available at: <http://kremlin.ru/events/president/news/63599?fbclid=IwAR0gRX6Rw7j bvy_zE8GgdUhlL4_YZEcS_tJeDiOzyctFwoEs9mRBhZooOqQ> [Accessed 06 June 2020].

Michel, Ch., Sassoli, D. and von der Leyen, U., 2020. Statement by Presidents Michel, Sassoli and von der Leyen on the 75th Anniversary of the Liberation of Auschwitz-Birkenau. European Council, 23 January [online]. Available 
at: <https://www.consilium.europa.eu/en/press/press-releases/2020/01/23/ message-by-presidents-sassoli-michel-and-von-der-leyen-on-the-75thanniversary-of-the-liberation-of-auschwitz-birkenau/> [Accessed 29 June 2020].

Miller, A., 2020a. Voīny pamyati vmesto pamyati o voīne [Memory Wars instead of War Remembrance]. Novaya gazeta, 05 May [online]. Available at: $<$ https://novayagazeta.ru/articles/2020/05/05/85240-voyny-pamyati-vmestopamyati-o-voyne?fbclid=IwAR3w6kE_PrqnNZX_KG-ZcPN5Sif5IfyYBVlKup3nbKly93wDOMLEFqgzoQ> [Accessed 29 June 2020].

Miller, A., 2020b. Vrag u vorot istorii [Enemy at the History's Gate]. Carnegie.ru, 05 May [online]. Available at: <https://carnegie.ru/ commentary/81207> [Accessed 29 June 2020].

Pobeda.rf, 2020a. Prezident vysoko otsenil novuyu ekspozitsiyu v Muzee Pobedy [The President Praised the New Exhibition at the Victory Museum]. IA Pobeda.rf, 9 May [online]. Available at: <https://pobedarf.ru/2020/05/09/prezident-vysokooczenil-novuyu-ekspozicziyu-muzeya-pobedy/> [Accessed 09 May 2020].

Pobeda.rf, 2020b. SK zavel delo o zverstvah finskih natsistov v Karelii [The Investigation Committee Files a Case on Finnish Nazis' Atrocities in Karelia]. IA Pobeda.rf, 24 April [online]. Available at: <https://pobedarf.ru/2020/04/24/ sk-zavel-delo-o-zverstvah-finskih-naczistov-v-karelii> [Accessed 29 June 2020].

Presentation, 2019. Prezentatsiya Goda pamyati i slavy [Presenting the Year of Memory and Glory]. Official website of the Irkutsk regional government [online]. Available at: <https://irkobl.ru/sites/apparat/75-anniversary/> [Accessed 06 June 2020].

Putin, V., 2018. Address of Vladimir Putin at the Meeting of the Pobeda (Victory) Organizing Committee [online]. Available at: <http://en.kremlin.ru/events/ president/news/59388> [Accessed 06 June 2020].

Putin, V., 2019. Address at the CIS Informal Summit. Official website of the President of the Russian Federation, 30 June [online]. Available at: <http:// en.kremlin.ru/events/president/transcripts/statements/62376> [Accessed 29 June 2020].

Putin, V., 2020a. Address of Vladimir Putin at the Meeting of the Pobeda (Victory) Organizing Committee [online]. Available at: <http://en.kremlin.ru/events/ president/news/63591> [Accessed 06 June 2020].

Putin, V., 2020b. 75th Anniversary of the Great Victory: Shared Responsibility to History and Our Future. Official website of the President of the Russian 
Federation, 19 June [online]. Available at: <http://en.kremlin.ru/events/ president/news/63527> [Accessed 29 June 2020].

Regnum, 2020. "Glotok svezhego vozduha" ["A Breath of Fresh Air”]. IA Regnum, 9 May [online]. Available at: <https://regnum.ru/news/society/2943929> [Accessed 01 July 2020].

RIA Novosti, 2019a. Bez sroka davnosti. SK zavel delo protiv veterana Latyshskogo legiona SS [No Limitation Period: The Investigation Committee Files a Case against the Waffen-SS Latvian Legion Veteran]. RIA Novosti, 26 September [online]. Available at: <https://ria.ru/20200811/1575624344. html> [Accessed 29 June 2020].

RIA Novosti, 2019b. SK nachal rassledovat' ubiīstvo 214 deteī v Yeīske natsistami [The Investigation Committee Launches an Inquiry on the Murder of 214 Children in Yeysk by Nazis]. RIA Novosti, 30 October [online]. Available at: $<$ https://ria.ru/20191030/1560393095.html> [Accessed 29 June 2020].

RIA Novosti, 2020a. Na stranitse soldata "Bessmertnogo polka” poyavilos' foto Gimmlera [A Picture of Himmler Surfaced on the Soldier's Page of "Immortal Regiment" website]. RIA Novosti, 10 May [online]. Available at: <https://ria. ru/20200811/1575624344.html> [Accessed 29 June 2020].

RIA Novosti, 2020b. FSB obnarodovala dokumenty o natsistskih chistkah v Rostove i Shahtah [The FSB Has Disclosed Documents on Nazis' Purges in Rostov and Shakhty]. RIA Novosti, 09 April [online]. Available at: $<$ https://ria. ru/20200409/1569819174.html> [Accessed 29 June 2020].

RIA Novosti, 2020c. GP planiruet vozobnovit' rassledovanie natsistskih zverstv v Krymu [Prosecutor General Office Plans to Resume Investigation of Nazis' Atrocities in the Crimea]. RIA Novosti, 09 April, [online]. Available at: <https:// ria.ru/20200430/1570790617.html> [Accessed 29 June 2020].

Uskov, O., 2020. Rezhisser "Legendy nomer 17" Nikolai Lebedev snimet fil'm "Niurnberg" [Nikolai Lebedev, Director of the "Legend No. 17" Movie, to Shoot "Nuremberg"]. Rossī̄skaya gazeta, 15 May [online]. Available at: <https:// rg.ru/2020/05/15/rezhisser-legendy-17-nikolaj-lebedev-snimet-film-niurnberg. html $>$ [Accessed 29 June 2020].

Victory Museum, 2020. Official website of the Victory Museum [online]. Available at: <https://victorymuseum.ru/museum-complex/glavnoe-zdanie-muzeya/ ekspozitsiya-podvig-naroda/> [Accessed 29 June 2020]. 
Yeltsin's Library, 2020. WWII in Archival Documents (Collection of Digitized Archival Documents, Film and Photo Materials. Boris Yeltsin's Presidential Library [online]. Available at: <https://www.prlib.ru/collections/1298142> [Accessed 29 June 2020].

Yushkov, M., 2020. SK zavel delo o genotside fashistami zhiteleī Stalingrada [The Investigation Committee Files a Case on Fascists' Genocide of Stalingrad Citizens]. RBC, 09 July [online]. Available at: <https://www.rbc.ru/society/09/ 07/2020/5f0703449a794702cec8992f?from=newsfeed $>$ [Accessed 08 July 2020].

Zachepa, E., 2020. Virtual'naya ekskursiya po Muzeyu truzhenikov tyla v Prohorovke [A Virtual Tour of the War Workers' Museum in Prokhorovka]. Mir Belogorya, 8 May [online]. Available at: <https://mirbelogorya.ru/regionnews/56-prokhorovka/36268-virtualnaya-ekskursiya-po-muzeyu-truzhenikovtyla-v-prokhorovke.html> [Accessed 29 June 2020]. 